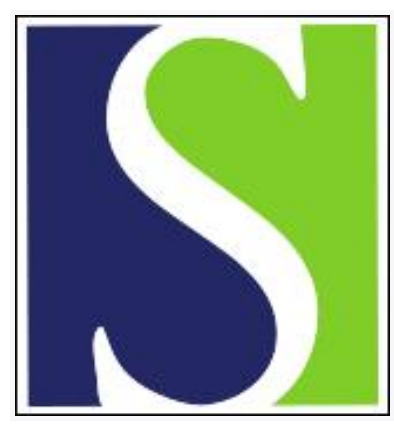

Scand J Work Environ Health 1977;3(1):43-52

https://doi.org/10.5271/sjweh.2791

Issue date: Mar 1977

A study on the distribution of methylchloroform and n-octane in the mouse during and after inhalation.

by Holmberg B, Jakobson I, Sigvardsson K

Key terms: 1,1,1-trichloroethane; distribution; inhalation; methylchloroform; mouse; n-octane; pharmacokinetics; solvent

This article in PubMed: www.ncbi.nlm.nih.gov/pubmed/847431

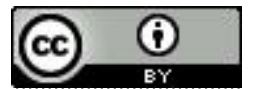


Scand. j. work environ. \& health 3 (1977) 43-52

\title{
A study on the distribution of methylchloroform and n-octane in the mouse during and after inhalation
}

\author{
by BO HOLMBERG, Ph.D., INGA JAKOBSON, B.Sc., and KARL SIGVARDSSON ${ }^{1}$
}

\begin{abstract}
HOLMBERG, B., JAKOBSON, I. and SIGVARDSSON, K. A study on the distribution of methylchloroform and n-octane in the mouse during and after inhalation. Scand. $j$. work environ. \& health 3 (1977) 43-52. The distribution of methylchloroform and n-octane, respectively, in the blood, liver, kidney, and brain of mice was studied at different inspired air concentrations and after different exposure times. The air concentration varied between 10 and $10,000 \mathrm{ppm}$; and the exposure time, between 0.5 and $24 \mathrm{~h}$. The resulting solvent concentrations in kidney and brain were about the same, but the liver concenitrations were usually somewhat higher for both solvents. There was a linear dependence between inspired air concentration and tissue concentrations at fixed exposure times. A correlation between blood and organ concentrations was observed in animals exposed at different inhalation air concentrations but not in animals exposed only at one fixed concentration. The ratios between the concentrations of the solvents in the organs and blood were higher for n-octane than for methylchloroform. The ratios increased as the exposure concentration increased for all organs studied in the case of n-octane but only for the liver in the case of methylchloroform. When the exposure dose, i.e., inspired air concentration $X$ time, was generated in different ways, a high concentration during a short exposure resulted in a ten times higher organ concentration than a low concentration during a long exposure. The liver, kidney, and brain concentrations generally did not differ more than twice between methylchloroform and n-octane after exposure of the same concentration and duration. The blood concentration, however, was much less in n-octane exposed animals than in methylchloroform exposed ones. A pharmacokinetic model with both uptake and elimination of the first order fitted the empirical data better for methylchloroform than a model with zero order uptake and first order elimination. Pastexposure concentrations of methylchloroform were linear in a semilog graph. A one-compartment pharmacokinetic model was in accordance with the experimental data for methylchloroform. For n-octane, however, at least a iwo-compantment model must be assumed.
\end{abstract}

Key words: distribution, methylchloroform, n-octane, pharmacokinetics, solvents, 1,1,1-trichloroethane.

For a good understanding of the toxic effect of a chemical compound it is not only necessary to know the body burden of the compound, but also the concentration in the critical tissues. The uptake of a

1 Section of Occupational Toxicology, National Board of Occupational Safety and Health, Stockholm, Sweden.

Reprint requests to: Dr. Bo Holmberg, Arbetarskyddsstyrelsen, Arbetsmedicinska avdelningen, Fack, S-100 26 Stockholm 34, Sweden. gas or vapor, such as an organic solvent, by the body at constant exposure continues until an equilibrium is reached between the concentrations of the substance in the various tissues and in the inspiratory air. Several authors have described the pharmacokinetics of the total uptake of organic solvents or volatile anesthetics after inhalation by using mathematical models $(6,9,11,12,16,17,18)$. Simulation studies have also been made so that the 
uptake of such compounds can be predicted according to electrical models $(7,14)$.

As there are great difficulties in getting information on the concentrations of chemical substances in different human tissues during or after exposure (19), investigations with animals are important. The literature on the tissue distribution of lipophilic substances in experimental animals during inhalation is, however, scarce (3). The present study was made in order to compare the distribution of two widely used organic solvents of different lipophilicity in three critical organs of mice. Methylchloroform and n-octane, n-octane being the most lipophilic of the two, were chosen mainly because their biotransformation is almost negligible.

\section{MATERIAL AND METHODS}

\section{Chemicals}

Methylchloroform was obtained from the Fisher Scientific Co., New Jersey, U.S.A., and n-octane from Merck-Schuchardt, Munich, Germany.

\section{Animals}

Commercial outbred albino male mice of the NMRI strain weighing $25-30 \mathrm{~g}$ were used.

\section{Exposure}

The exposure chamber was an exsiccator (12 1) fitted with an inlet tube for the vapor. An infusion pump (Dauer Unita I, B. Braun), joined to an injection syringe containing the solvent, forced the solvent at a slow constant rate into a glass tube which was heated by a metal coil so that vapor would be generated. The solvent vapor was mixed with air and let into the chamber at a constant rate $(5 \mathrm{l} / \mathrm{min})$. Regulating the temperature of the heating coil and the speed of the infusion pump allowed the chamber air concentration to be controlled. The concentration of the solvent in the exposure chamber (10$10,000 \mathrm{ppm}$ ) was repeatedly determined by gas chromatography during exposure.
Groups of mice (3-10 animals) were exposed for different time periods from 0.5 to $24 \mathrm{~h}$. The exposure was run one to four times with different groups of animals but with the same solvent concentration and exposure time. Before inhalation the animals were given $0.2 \mathrm{ml}$ of $2 \%$ heparin intraperitoneally. Food and water was withdrawn during the exposure. When exposure was terminated, the animals were killed immediately, unless otherwise stated, by dislocation of the spinal cord.

\section{Analysis}

The liver, kidneys, and brain of the animals were removed as soon as possible after the sacrification, and blood was collected by heart puncture. Aliquots from the tissues and whole blood (about $0.4 \mathrm{~g}$ ) were put into beakers with ice-cooled ethanol $(10 \mathrm{ml})$ and were homogenized by an Ultraturrax apparatus under cooling. Homogenization was performed during less than $0.5 \mathrm{~min}$. The samples were then transferred to glass bottles $(25 \mathrm{ml})$, which were immediately closed with aluminium caps fitted with rubber membranes. The samples were left standing for at least $1 \mathrm{~h}$ at room temperature before analysis so that equilibrium would be obtained. After equilibration $0.3-\mathrm{ml}$ air samples from each bottle were taken with a gas-tight syringe and injected into a Varian 1700 Aerograph gas chromatograph. A $10 \%$ UCON-Polar on Chromosorb M (100-120 mesh) column, thermostated at $90^{\circ} \mathrm{C}$, was used for the methylchloroform samples, and a $20 \%$ Polyetyleneglykol 400 on Chromosorb W (60-80 mesh) column, thermostated at $80^{\circ} \mathrm{C}$, for the $\mathrm{n}$-octane samples. An electron-capture detector was used for methylchloroform; and a flame ionization detector for n-octane. In both cases the carrier gas was nitrogen which flowed at a rate of $30 \mathrm{ml} / \mathrm{min}$.

The amount of solvent in each tissue sample was calculated after comparison with samples from standard solutions in ethanol and was the mean of at least two separate determinations from each bottle. Tissue samples from unexposed animals were homogenized in the presence of standard solutions of methylchloroform or $\mathbf{n}$ octane in ethanol. No loss of solvent could 
be detected during the homogenization, as performed.

\section{Pharmacokinetic theory}

In pharmacokinetic theory the concentration of a drug in blood plasma (C) at different times ( $t$ ) and at a constant uptake is commonly supposed to have a rate constant of zero order for retention and of first order for elimination (8); the result is the following mathematic relation:

$$
\mathrm{C}=\mathrm{A}_{1}-\mathrm{A}_{2} \cdot \mathrm{e}^{-\boldsymbol{a} \cdot \mathrm{t}}
$$

where $A_{1}, A_{2}$, and $\alpha$ are constants.

The same relation is often observed for the uptake of anesthetic gases from alveoli to blood (8). The equation is due to a onecompartment pharmacological model.

A more complex model is sometimes used, e.g., the three-compartment model that is used for describing the pharmacokinetics of toluene and benzene (18) and has the following equation:

$$
\begin{aligned}
& C=A_{1}\left(1-\mathrm{e}^{-\alpha_{1} \cdot t}\right)+A_{2}\left(1-\mathrm{e}^{-\alpha_{2} \cdot t}\right) \\
& +A_{3}\left(1-\mathrm{e}^{-\alpha_{3} \cdot t}\right),
\end{aligned}
$$

where $A_{1}, A_{2}, A_{3}, \alpha_{1}, \alpha_{2}$, and $\alpha_{3}$ are constants.

When the uptake is not constant with time at a constant inspired air concentration, the blood plasma concentration may follow a bi-exponential model:

$$
\mathbf{C}=\mathbf{A}_{1} \cdot \mathrm{e}^{-\alpha_{1} \cdot t}-\mathbf{A}_{2} \cdot \mathrm{e}^{-\alpha_{2} \cdot t} .
$$

This model corresporids to a first-order equation for both retention and elimination (8), but it is not necessary to assume more than one pharmacologic compartment. Regression analysis, using empirical data, was used in the comparison of equations $1-3$.

\section{Regression analysis}

A regression analyisis of different data sets was performed with two techniques.

1. Linear regression. Desk calculators (Compucorp 445 and 145 Statistician) were used for the calculation of the parameters in the mathematical models and the predicted values of the dependent variable after linear regression (equations 4 and 5).

$$
\begin{aligned}
& y=a+b x \\
& \ln y=a+b \cdot \ln x
\end{aligned}
$$

2. Nonlinear regression. The pharmacokinetic models (equations 1-3) were fitted to empirical data by a Gauss-Newton nonlinear regression program (BMDP $3 R$, University of California, Los Angeles) with an IBM-360 computer.

The comparison of alternative models (j) was based on the examination of the residual sum of squares

$$
\mathrm{y}_{\mathrm{j}}=\sum_{\mathrm{i}=1}^{\mathrm{n}}\left(\mathrm{C}_{\mathrm{i}}-\mathrm{C}_{\mathrm{ij}}\right)^{2} \text {, }
$$

where $C_{i}$ and $C_{i j}$ were the experimental and predicted concentrations in the i-th experimental point. For discrimination, the criteria of Mannervik and Bartfai (13) were used.

\section{RESULTS}

\section{Tissue concentrations}

The concentrations of the solvents in blood, liver, kidney, and brain are shown in tables 1 and 2. As seen in table 1, the concentrations of methylchloroform in blood, kidney, and brain were generally of the same magnitude for a given exposure time. The liver concentration of methylchloroform seemed to be slightly higher than the concentrations in the other tissues. For n-octane, the liver, brain, and kidney concentrations were generally much higher than the blood concentration, a tendency which increased with increasing inspired air concentration (table 2). The concentrations in an organ at a particular inspired air concentration and exposure time did not generally differ more than twice between methylchloroform and n-octane, the blood concentrations generally being much lower for n-octane than for methylchloroform (tables 1 and 2). 
Table 1. Concentrations of methylchloroform in tissues at different inspiratory air concentrations and exposure durations: means and standard deviatioms. Number of animals indicated in parentheses. Concentrations in $\mu \mathrm{g}$ of methylchloroform per gram of tissue (wet weight).

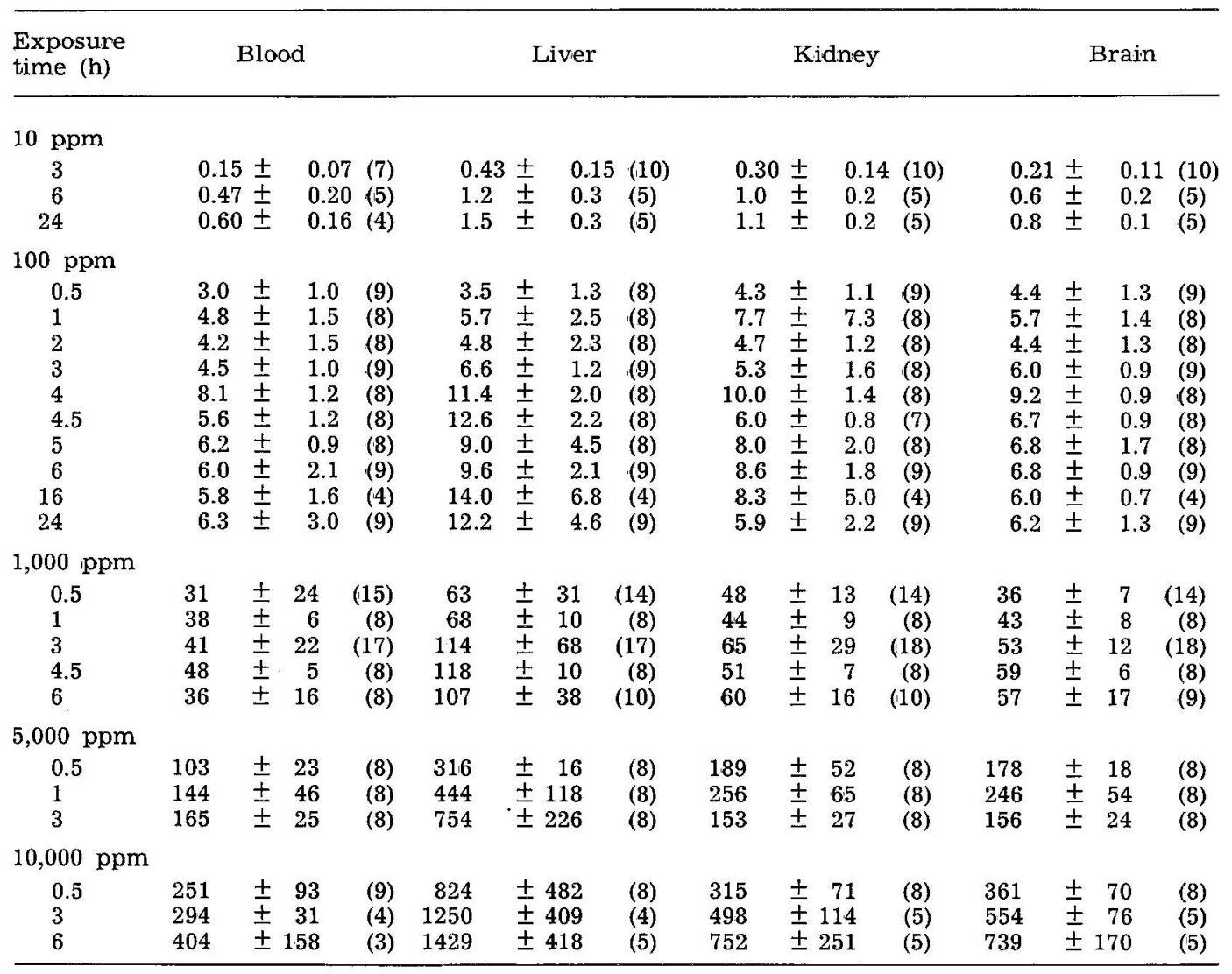

Table 2. Concentrations of n-octane in tissues at different inspiratory air concentrations and exposure durations: means and standard deviations. Number of animals indicated in parentheses. Concentrations in $\mu \mathrm{g}$ of $\mathrm{n}$-octane per gram of tissue (wet weight).

\begin{tabular}{|c|c|c|c|c|c|c|c|c|c|c|c|c|c|c|c|c|}
\hline $\begin{array}{l}\text { Exposure } \\
\text { time (h) }\end{array}$ & \multicolumn{4}{|c|}{ Blood } & \multicolumn{4}{|c|}{ Liver } & \multicolumn{4}{|c|}{ Kidney } & \multicolumn{4}{|c|}{ Brain } \\
\hline \multicolumn{17}{|l|}{$100 \mathrm{ppm}$} \\
\hline 0.5 & 10.4 & \pm & 3.3 & (4) & 6.1 & \pm & 3.4 & (5) & 11.5 & \pm & 1.0 & (5) & 7.7 & \pm & 2.2 & (5) \\
\hline 3 & 7.4 & \pm & 2.5 & (15) & 2.4 & \pm & 1.0 & (15) & 2.8 & \pm & 0.9 & (15) & 3.8 & \pm & 1.2 & (15) \\
\hline \multicolumn{17}{|l|}{1,000 ppm } \\
\hline 0.5 & 8.2 & \pm & 2.8 & (7) & 20 & \pm & 8 & (18) & 20 & \pm & 5 & (18) & 32 & \pm & 9 & (17) \\
\hline 1 & 9.4 & \pm & 4.1 & (8) & 35 & \pm & 7 & (8) & 47 & \pm & 10 & $(8)$ & 40 & \pm & 8 & (8) \\
\hline 2 & 11 & \pm & 6 & (10) & 66 & \pm & 21 & (12) & 52 & \pm & 19 & (10) & 54 & \pm & 7 & (12) \\
\hline 3 & 14 & \pm & 4 & (12) & 54 & \pm & 13 & (18) & 39 & \pm & 10 & (18) & 47 & \pm & 8 & (18) \\
\hline 4 & 9 & \pm & 4 & (8) & 56 & \pm & 8 & (8) & 56 & \pm & 16 & (8) & 48 & \pm & 3 & (8) \\
\hline 5 & 10 & \pm & 6 & (8) & 61 & \pm & 9 & (8) & 64 & \pm & 13 & (8) & 48 & \pm & 10 & (8) \\
\hline 6 & 11 & \pm & 2 & (4) & 45 & \pm & 12 & $(20)$ & 45 & \pm & 21 & (19) & 45 & \pm & 9 & (20) \\
\hline 18 & & - & & & 178 & \pm & 76 & (12) & 77 & \pm & 20 & (12) & 51 & \pm & 7 & (12) \\
\hline 20 & & - & & & 122 & \pm & 38 & (8) & 119 & \pm & 43 & (8) & 57 & \pm & 8 & (8) \\
\hline \multicolumn{17}{|c|}{$10,000 \mathrm{ppm}$} \\
\hline 0.5 & 95 & \pm & 18 & (12) & 1011 & & 254 & (12) & 467 & \pm & 54 & (12) & 622 & \pm & 63 & (12) \\
\hline 3 & 155 & \pm & 37 & (15) & 1640 & \pm & 233 & (15) & 945 & \pm 1 & 126 & (15) & 912 & \pm & 81 & (15) \\
\hline
\end{tabular}




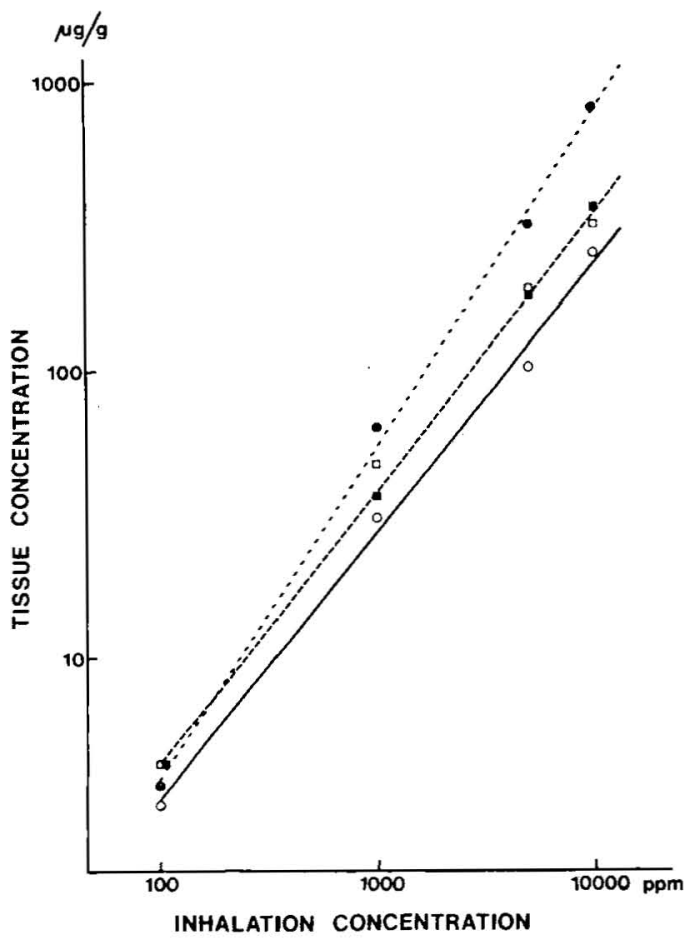

Fig. 1. Concentrations of methylchloroform in tissues after $30 \mathrm{~min}$ of exposure at different concentrations of methylchloroform. The lines were fitted to the data after regression analysis (equation 5 of the materials and methods section). [Blood (o-o), liver (-- - $)$, kidney $(\square---\square)$ and brain ( $\square---\mathbf{a})$ ]

Correlation between inspired air and tissue concentrations

For methylchloroform there was a fairly good correlation between the inspired air concentration and the tissue concentrations at different exposure times. As an example of how the empirical data fitted the curves after regression analysis (equation 5), the different tissue concentrations of methylchloroform inhaled during $30 \mathrm{~min}$ are shown in fig. 1. For n-octane, the results were similar to these for methylchloroform for all organs, but for blood the empirical data did not fit a linear curve well.

\section{Correlation between organ and blood concentrations}

When the solvent concentrations in the organs were compared with those in blood

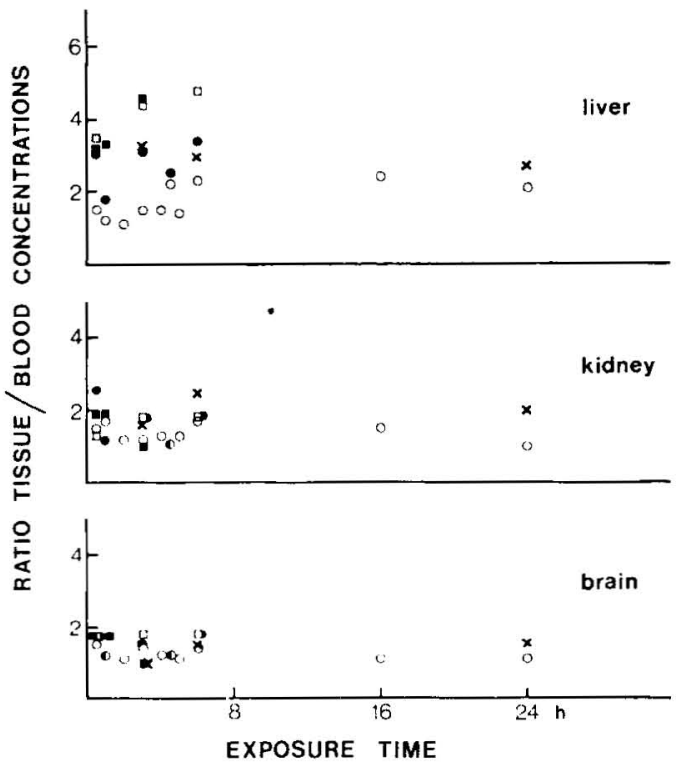

Fig. 2. Ratios between concentrations of methylchloroform in various organs and blood after different lengths of exposure. [10 $\mathrm{ppm}(\mathrm{x})$,

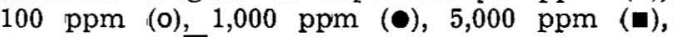
$10,000 \mathrm{ppm}(\square)]$

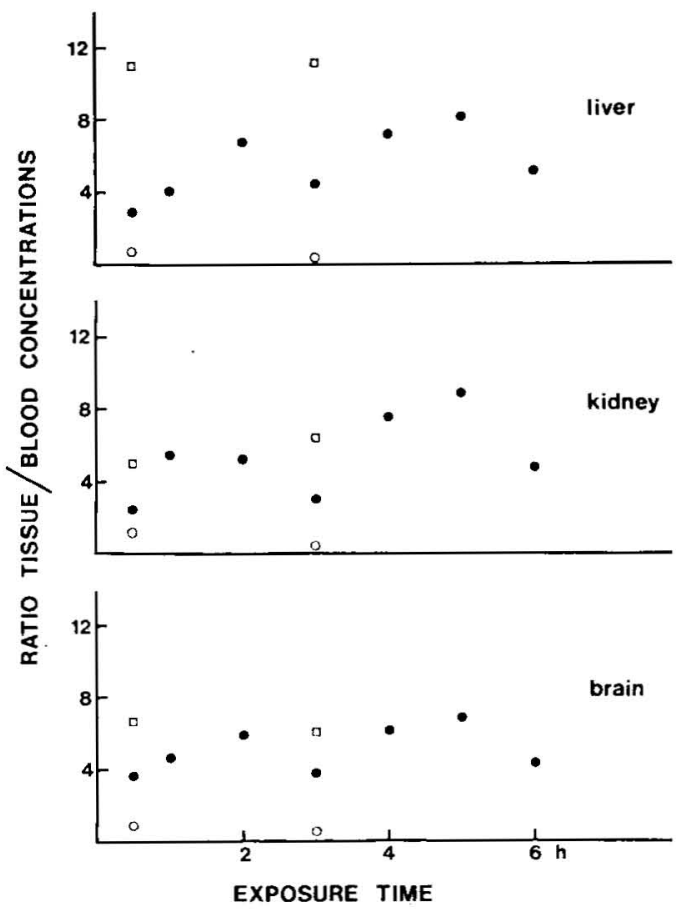

Fig. 3. Ratios between concentrations of nootane in various organs and blood after different lengths of exposure. [100 ppm (o), $1,000 \mathrm{ppm}(\bullet), 10,000 \mathrm{ppm}(\square)]$ 


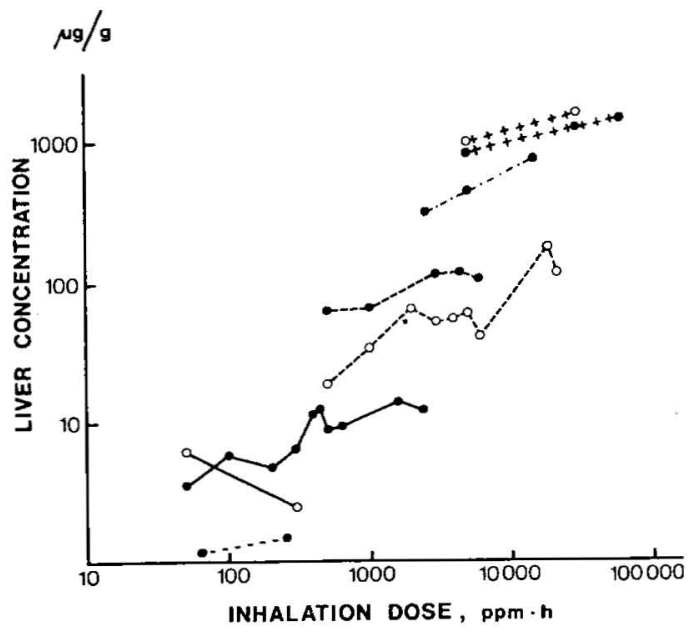

Fig. 4. Concentrations of methylchloroform and $n$-octane in liver at diffenent inhalation doses. [Methylchloroform (e), n-octane (0), $10 \mathrm{ppm}$ (- - ), 100 ppm (-), 1,000 ppm (- - - ), 5,000 ppm $(-\cdot-), 10,000$ ppm $(++++)]$

(equation 4), the correlation was low for a given time and a given inspired air concentration, as well as for different times of exposure and a given inspired air concentration, for both solvents. A high organ concentration of solvent in one animal was thus not always accompanied by a high concentration in the blood of the same animal, neither did it correlate with high concentrations in the other organs from the same animal. When data for all inspired air concentrations and exposure times of all animal groups were treated together, a correlation was observed $(r \geq$ 0.89 for methylchloroform and $r \geq 0.91$ for $\mathrm{n}$-octane) between the blood and organ concentrations.

The ratios between the organ and blood concentrations of all individual animals were calculated, as well as the means of the ratios of all animals exposed to the same concentration for the same length of time (figs. 2 and 3). The ratios were generally lower for methylchloroform (fig. 2) than for n-octane (fig. 3). There was no obvious difference in ratios between the different organs studied except for the liver in the case of methylchloroform, nor was there a clear-cut tendency toward a change in ratios with a change in exposure time for any of the solvents. An increase in the inspired air concentration of n-octane resulted, however, in an enrichment of this solvent in all organs studied, i.e., the organ/blood concentration ratios increased as the air concentration increased. The differences between any two points at the same exposure time for n-octane were always statistically significant $(\mathrm{p} \leq$ $0.05)$ and the significance was still higher $(p \leq 0.001)$ for 15 out of the 18 pairs of points possible to compare (fig. 3). For methylchloroform, an increase in ratio with increasing air concentration was observed for liver/blood only (fig. 2). This tendency was less marked for methylchloroform than for n-octane.

\section{Constant dose}

The concentrations of both solvents in the organs at different inspired doses, i.e., the

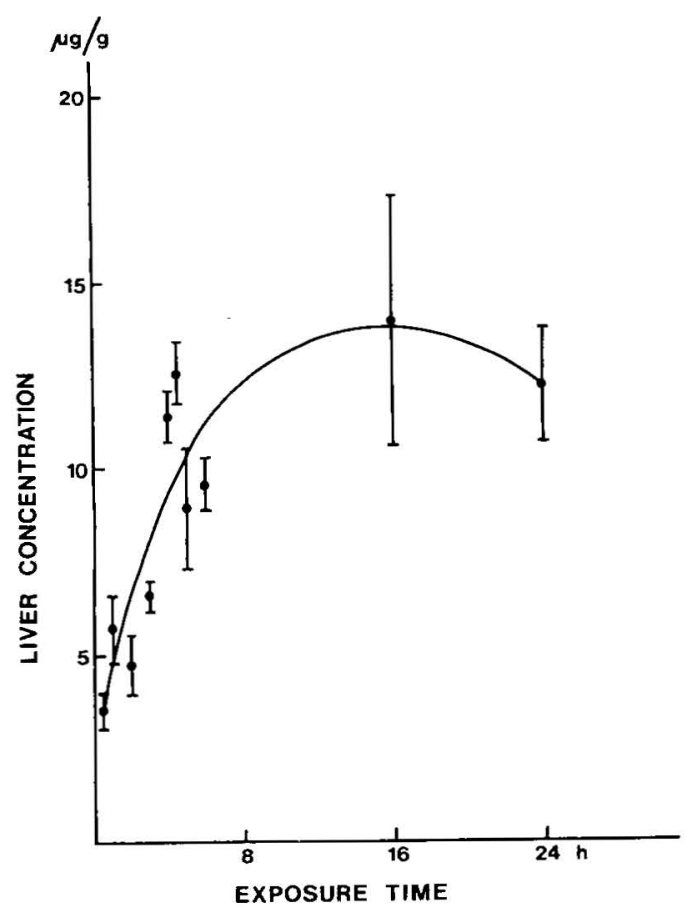

Fig. 5. Concentrations of methylchloroform in liver after different lengths of exposure to $100 \mathrm{ppm}$. Observed data (means \pm standard error of the mean) (0) and data pnedicted according to equation $\mathbf{3}$ of the materials and methods section (-). 


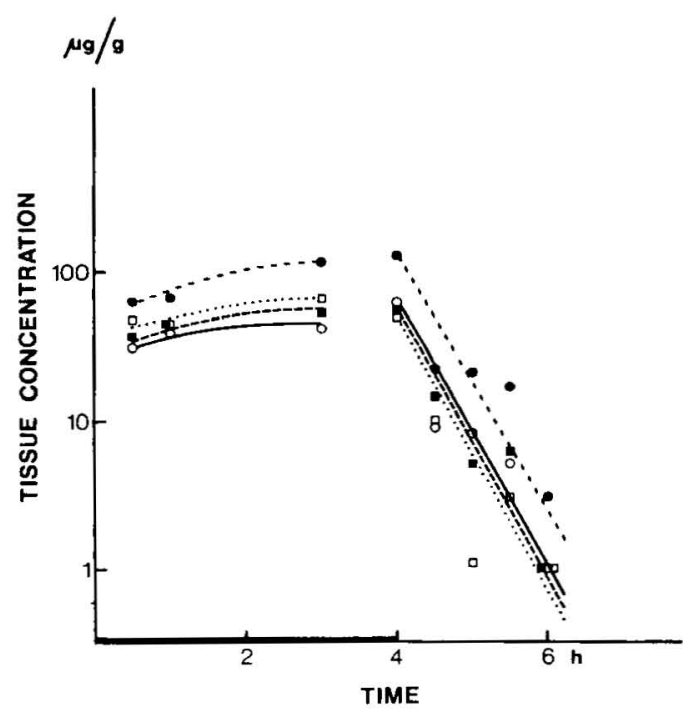

Fig. 6. Concentrations of methylchloroform in tissues $0-2 \mathrm{~h}$ after $4 \mathrm{~h}$ of exposure at 1,000 ppm (see the text). The data during exposure time $(0.5-3 \mathrm{~h})$ come from table 1 . [Blood (o0 ), liver (๑ - - $\bullet$ ), kidney $(\square \ldots \ldots \square)$ and brain $(\mathbf{\square - -}-\mathbf{\square})]$

air concentration $X$ the corresponding exposure time, were calculated. As shown in fig. 4, the liver concentration could be more than ten times greater when the animals were given a high inspired air concentration during a short exposure time than when a low inspired air concentration was administered during a long exposure time. The same tendency was obtained for the other tissues studied. As noted previously, the concentrations in the particular organs were roughly the same for both solvents at the same inhalation dose.

\section{Time-dependent tissue concentrations}

The concentrations of methylchloroform and $\mathrm{n}$-octane in the different tissues after exposure to 100 and $1,000 \mathrm{ppm}$, respectively, were compared to different mathematical models of kinetics (equations $1-3$ and some polynomial functions). Equation 3 fitted the empirical data best for all tissues for methylchloroform. For n-octane, however, the fitness for all the tissues analyzed was about the same for equations 1 and 3. Statistically significant differences, as tested by the F-test, between the models for different data sets could not be shown for any of the two solvents because the standard deviations of the concentrations in different animals were too high. A plot of observed and predicted data for the liver concentrations of methylchloroform, as described by equation 3 , is shown in fig. 5.

\section{Elimination studies}

Tissues from ten mice exposed to 1,000 ppm methylchloroform for $4 \mathrm{~h}$ were analyzed for postexposure tissue concentrations (fig. 6). As seen, the concentrations were linear with time in a semilog graph. The biological half-time of methylchloroform was about $20 \mathrm{~min}$ for all the tissues analyzed.

The postexposure concentrations of tissues from ten mice exposed to $5,000 \mathrm{ppm}$ n-octane for $4 \mathrm{~h}$ were also determined (fig. 7). This figure shows that the elimination curve was not linear, but could be approximated by two straight lines for each tissue.

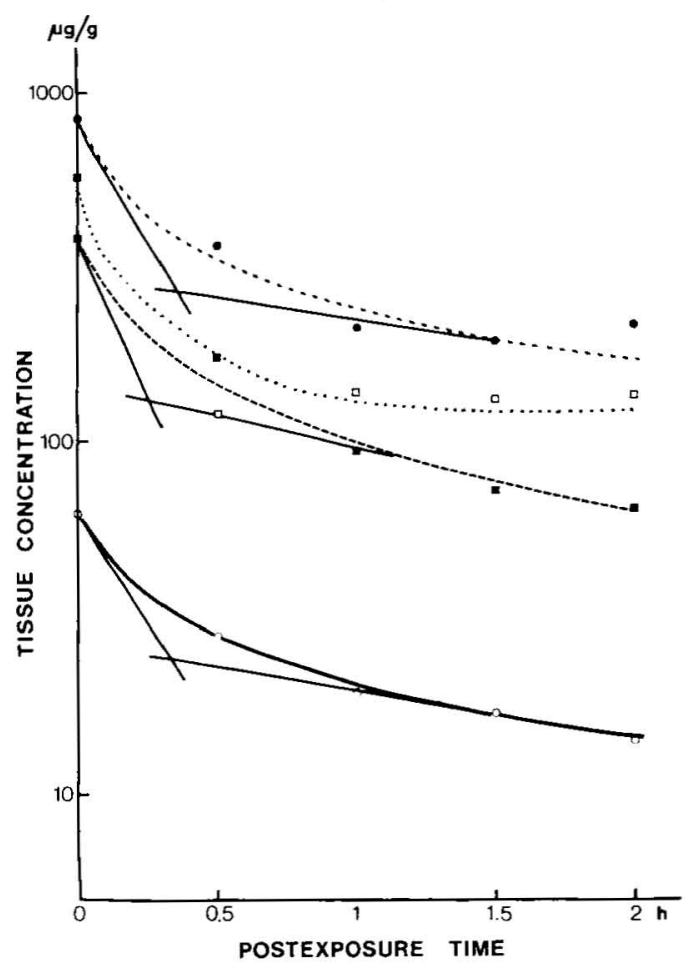

Fig. 7. Concentrations of n-octane in tissues $0 \longrightarrow 2 \mathrm{~h}$ after $4 \mathrm{~h}$ of exposune at $5,000 \mathrm{ppm}$. [Blood $(0-0)$, liver $(\bullet-\ldots)$, kidney $(\square \ldots . . \square)$, brain ( $\mathbf{\square}---\square)$ and asympitotes $(-)]$ 


\section{DISCUSSION}

The vapor of an organic solvent is resorbed by capillary blood at the alveolus in proportion to its solubility in blood. The organic solvent, dissolved in blood plasma or blood cell membranes or bound to blood protein, diffuses into distant tissues as it is transported around the body.

Some portions of a solvent may be biotransformed, not only in the liver, but also in other tissues. Biotransformation products of organic solvents do not, with a few exceptions, generally possess anesthetic properties. Biotransformation products are eliminated via the urine if they are water soluble; volatile products are returned by venous blood to the alveoli and exhaled. In some cases, such as for the presently investigated methylchloroform (20) and n-octane (21), the biotransformation rate is very low and the majority of resorbed solvent is thus exhaled untransformed.

One aim of this distribution study was to investigate the time course of changes in solvent concentrations in different tissues during short-time inhalation at different concentrations. The primary interest was to study potential target organs with a rich blood supply, namely, the liver, kidney and brain, for two slowly biotransformed organic solvents of different liposolubility. Fat tissues were not studied because of the minimal amount in young mice.

The solvent concentration of liver, kidney, brain, and blood was directly proportional to the concentration of the vapor in the inspired air at any given length of exposure. The conclusion cannot be drawn, however, that there is a simple relationship between inspired-air solvent concentration and the corresponding tissue concentration. The present data indicate a lower blood uptake of the more lipophilic n-octane than of methylchloroform at the same inspired air concentration and length of exposure. The water solubility of n-octane is $2 \mathrm{mg}$ in $100 \mathrm{ml}$ at $25^{\circ} \mathrm{C}$ and that of methylchloroform is $132 \mathrm{mg}$ in $100 \mathrm{ml}$ at $20^{\circ} \mathrm{C}$ (2). Physical characteristics of a solvent are thus as important as parameters in the toxicokinetics of organic solvents $(1,6$,$) as they are in determining$ the anesthetic potency of volatile anesthet- ics (15). The physical characteristics are important also to the other biological effects of organic solvents, e.g., for the cell membrane stabilization effect of hypotonically incubated erythrocytes (10).

There were furthermore differences in the concentration of each solvent in the different critical organs. Thus the liver concentration was higher than the concentration in kidney and brain, especially at a high inspired air concentration.

The difference between liver and the other vessel rich target tissues was much less for n-octane than for methylchloroform, but was observed at high inspired air concentrations. Higher concentrations in the liver than in kidney and brain have been obtained for chloroform in the mouse (3), although the method of analyzing the chloroform did not discriminate between the inhaled compound and its biotransformation products. However, the difference between the chloroform concentrations in the liver and other organs was observed as early as $10 \mathrm{~min}$ after the start of exposure.

When the organ concentrations of both solvents were compared to the actual blood concentrations, the lipophilic n-octane showed much higher organ/blood concentration ratios than the more hydrophilic methylchloroform. The difference in ratios did not change over time. The ratios were highly dependent on inspired air concentrations, at least for n-octane, and had an organ/blood concentration ratio 30 times higher at $10,000 \mathrm{ppm}$ than at 100 ppm. The organ concentration thus does not simply depend on the blood concentration but seems proportionally higher at a higher inspired air concentration, at least for the lipophilic n-octane. The kidney/ blood and brain/blood concentration ratios for methylchloroform were constant at all inspired air concentrations studied. The increase in the liver/blood concentration ratio as inspired air concentrations increased was not as marked for methylchloroform as for n-octane.

The statement that the blood concentration did not give a good picture of the real organ concentrations was also supported by results from individual animals and by the analyses of the correlation between blood and organ concentrations at fixed inspired air concentrations. 
In accordance with pharmacokinetic theory, the tissue concentrations were generally found to be higher after a high inspired air concentration $\times$ a short exposure time than after a low inspired air concentration $\times$ a long exposure time, the result being the same ppm $\times$ hour value. This phenomenon was observed for both solvents and all tissues, but was especially marked for the liver. Short-time peak exposures to organic solvents may thus result in much higher loads to critical vessel-rich tissues than low exposure levels continued during a longer period of time.

The comparison between the mathematical models for pharmacokinetics demonstrated that the model (equation 3) describing first order kinetics in both retention and elimination in all tissues showed the best fitness to empirical data for methylchloroform. In the case of n-octane, however, a better fitness was not obtained when an exponential term for retention was introduced.

The graphical description of equation 3 shows a maximum (fig. 5). Should this model be common in the toxicokinetics of organic solvents, it is important not only to determine the solvent concentration in tissues at a fixed time after the start of exposure, but also to know the time course of tissue concentration changes.

The statistical treatment of data from individual organs does not permit any discussion of the number of theoretical compartments in the body. The postexposure curves for methylchloroform and n-octane in blood may, however, be used for such a discussion. The elimination data of methylchloroform, giving a linear dependence with time for the concentrations of methylchloroform in blood as well as in the organs studied, are in accordance with a one-compartment model as described by equation 3 . In contrast to the results for methylchloroform the onecompartment model did not fit the empirical data well for $n$-octane; this finding suggests that at least a two-compartment model offers a better description of the toxicokinetics of n-octane. However, further investigation is warranted.

Linear curves of postexposure concentrations in the blood have also been observed for other solvents, e.g., for hydrophilic acetone in man and dogs (5) On the other hand, lipophilic solvents usually show nonlinear elimination curves for blood, as well as for alveolar or expiratory air in man $(1,4,18)$. Species differences may be significant since Asstrand (1) found nonlinear postexposure curves for methylchloroform in man in contrast to our results in the mouse.

It should be noted that liver, kidney, and brain are all vessel rich organs, which are considered by some authors $(6,16,18)$ to belong to the same theoretical compartment. The fact that a one-compartment model fits the empirical data well does not prove that this model is the true one. Theoretically, any tissue is a compartment of its own, and, in addition, tissues are certainly composed of different subcompartments, each theoretically playing a role in the physiological response and the biotransformation of volatile compounds. Thus, from a theoretical point of view, a multicompartment model would be the most satisfactory one for each organ, as well as for the whole body, and it is important to keep in mind that any deviation from that view is an oversimplification of the true dynamics of organic solvents.

\section{ACKNOWLEDGMENTS}

The authors wish to acknowledge the valuable criticism offered by Prof. Irma Åstrand and Drs. Bengt Mannervik and Tomas Lindqvist and the valuable discussions of Dr. Östen Einarsson.

\section{REFERENCES}

1. ÅSTRAND, I. Uiptake of solvents in the blood and tissues of man: A review. Scand. j. work environ \& health. 1 (1975) 199-218.

2. BEILSTEIN, F. K. Beilsteins Handbuch der organischen Chemie. Vierte Auflage Drittes Ergänzungswerk. Erster Band. Springer-Verlag Berlin, Göttingen, Heidelberg 1958. $1143 \mathrm{p}$.

3. COHEN, E. N. and HOOD, N. Application of low-tempenature autoradiography to studies of the uptake and metabolism of volatile anesthetics in the mouse: I. Chlonoform. Anesthesiology 30 (1969) 306-314.

4. DIVICENZO, G, D, YANNO, F. J. and ASTILL, B. D. Human and canine exposures to methylene chloride vapor. $A m$. ind. hyg. assoc. j. 33 (1972) 125-135. 
5. DIVINCENZO, G. D., YANNO, F. J. and ASTILL, B. D. Exposure of man and dog to low concentrations of acetone vapor. $A m$ ind. hyg. assoc. j. 34 (1973) $329-336$.

6. EGER, E. I. A mathematical model of uptake and distribution. In: E. M. PAPPER and R. I. KITZ (edis.), Uptake and distribution of anesthetic agents, McGraw-Hill, New York, N. Y. 1963, pp. 72-87.

7. FISEROVA-BERGEROVA, V., VLACH, J. and SINGHAL, K. Simulation and prediction of uptake, distribution, and exhalation or organic solvents. $B r . j$. ind. med. 31 (1974) 45-52.

8. GOLDSTEIN, A., ARONOW, L. and KALMAN, S. M. Principles of drug action: The basis of pharmacology. Harper \& Row, New York, N. Y. 1968. 884 p.

9. GUBERAN, E. and FERNANDEZ, J. Control of industrial expasure to tetrachlonoethylene by measuring alveolar concentrations: Theoretical approach using a mathematical model. $B r . j$. ind. med. 31 (1974) $159-167$.

10. HOLIMBERG, B., JAKOBSON, I. and MALMFORS, T. The effect of organic solvents an erythrocytes during hypotonic hemolysis. Environ. res. 7 (1974) 193-205.

11. IKEDA, M. and IMAMURA, T. Biological half-life of itrichloroethylene and tetnachlonoethylene in human subjects. Int. Arch. Arbeitsmed. 31 (1973) 209-224.

12. KETY, S. S. The theory and applications of the exchange of inert gas at the lungs and tissues. Pharmacol. rev. 3 (1.951) $1-41$.

13. MANNERVIK, B. and BARTFAI, T. Dis- orimination between mathematical models of biological systems exemplified by enzyme steady sitate kinetics. Acta biol. med. ger. 31 (1973) 203-215.

14. MAPLESON, W. W. An electric analogue for uptake and exchange of inert gases and other agents. J. appl. physiol. 18 (1963) 197-204.

15. MILLER, K. W., and SMITH, E. B. Intermolecular forces and the phanmacology of simple molecules. In: R. M. FEATHERSTONE (ed.), A guide to molecular pharmacology-toxicology, Part II. Dekker, Inc., New York, N. Y. 1973, pp 427-475.

16. PERL, W., LESSER, G. T. and STEELE, J. M. The kinetics of distribution of the fat-soluble inert gas cyclopropane in the body. Biophys. $j$. 1 (1960) 111-135.

17. RACKOW, H., SALANITRE, E., EPSTEIN, R. M., WOLF, G. L. and PERL, W. Simultaneous uptalke of $\mathrm{N}_{2} \mathrm{O}$ and cyclopnopane in man as a test of compantment model. J. appl. physiol. 20 (1965) 611-620.

18. SATO, A., NAKAJIMA, T., FUJIWARA, Y., and HLROSAWA, K. Pharmacokinetics of benzene and itoluene. Int. Arch. Arbeitsmed. 33 (1974) 169-182.

19. SHERWOOD, R. J. Benzene: The interpretation of manitoring nesults. Ann occup. hyg. 15 (1972) 409-421.

20. STEWART, R. D. The toxicology of $1,1,1-$ trichlonoethane. Ann. occup. hyg. 11 (1968) $71-79$.

21. WILLIAMS, R. T. Detoxication mechanisms. Chapman \& Hall, Ltd., London 1959 $796 \mathrm{p}$.

Received for publication: 1976-09-13

The aim of the Scandinavian Journal of Work, Environment and Health is to promote research concerning occupational health and the work environment. One of the ways it attempts to fulfill this aim is to publish review articles on subjects related to work in the following fields: medicine, toxicology, epidemiology, hygiene, safety, ergonomics, sociology, psychology, and physiology. The Journal attempts to include at least one such article in each of the four regular issues per year to help the readers cope with the ever-increasing output of scientific reports.

The Journal invites all those interested to submit such articles and will pay a nominal fee for any review article accepted for publication. 